\title{
DESIGN STRATEGIES FOR INTEGRATING BIOPHILIC DESIGN TO ENHANCE THE STUDENTS' PERFORMANCE IN EXISTING PRIMARY SCHOOLS IN EGYPT
}

\author{
Ashrakat Sayed ${ }^{a}$, Gehan Nagy ${ }^{\text {** }}$ \\ ${ }^{a}$ Student at the British University in Egypt (BUE), Faculty of Engineering, Architectural \\ Engineering Department, El Sherouk City, Egypt \\ ${ }^{\mathrm{b}}$ Associate Professor at the British University in Egypt (BUE), Faculty of Engineering, \\ Architectural Engineering Department, El Sherouk City, Egypt
}

\begin{abstract}
Schools are the most important buildings that affect the generation's way of thinking and way of living. Egypt is one of the countries that experience many problems in its current design practices in their school building's design strategies. Most of the schools are neglecting the impact of linking classrooms with outdoor spaces on the student's behavior and way of learning. Students need to feel free, relaxed and motivated in order to be more effective and productive. There are various types of interior designs that could enhance the classroom's interior space, so that it can be more comfort and interesting to students. Biophilic design is one of the sustainable design solutions that could maintain the ability of having indoor spaces linked with the outdoor space through the use of plants, daylighting, textures, materials and colors. The aim of this research is to propose a set of strategies for integrating Biophilic design to enhance students' performance in exiting primary schools in Egypt. The methodology adopted is divided to three parts. The first part will define the Biophilic design and its impact on the student's health and performance. The second part will clarify the Biophilic design elements and frameworks to identify the suitable elements for the classroom's interior design. The third part will discuss the design considerations to implement these elements in the classroom's interior design. According to the three parts the final conclusion will specify a matrix linking between the Biophilic design strategies and the student's health and performance. The result expected from the matrix will identify the suitable Biophilic design strategies to be
\end{abstract}

implemented in the school's classrooms to enhance the student's health and performance.

Keywords: biophilic design, indoor green spaces, education in Egypt, design strategies, student's performance

\section{Introduction}

Education is one of the main process that has a big influence on the environment. So that enhancing the schools design strategies should be taken in consideration. The design of the school's interior spaces affects the students' performance. Therefore, classrooms should be designed in a manner that stimulates, comforts and, cheers students (Kahn, 1997; Kaplan \& Kaplan, 1998; Kellert, 2005; Kellert \& Wilson, 1993). They need spaces that will make them more effective, more excited and full of power (Griffin, 2004). In Egypt, school designs are based on traditional designs, which eliminates the idea of feeling the surrounded environment through the indoor spaces "classrooms". Students should be exposed to nature and this could be done by implementing new sustainable design strategies for the school classrooms. This research will introduce one of the sustainable designs "the Biophilic design" that can be implemented in local actual school's conditions. This design can have a positive impact on the student's mental and physical health. Students are affected physically by enhancing their physical activities, reduces the blood pressure, improved the sense of comfort and satisfaction, reduces the signs of illness and improved their health. Mentally by their behavior, attendance, attention and concentration. They are emotionally improved by releasing the stress with calmness and relaxation. 


\section{Biophilic Design and its importance}

According to Kellert and Finnegan study in 2011 Biophilia is defined as the innate biological connection between human kind and nature. The Biophilic design also has another definition a process that can translate the meaning of the attraction of the human to the natural environment into the design of the built environment (Wilson 1984, Kellert and Wilson 1993). Kellert and Elizabeth in 2015 proved that applying the Biophilic design in the educational spaces will affect the student's mental and physical behavior; by allowing the students to feel the nature inside the classrooms. Moreover, the implementation of the Biophilic design is an affordable process that can be used in different school's standards; international or even public schools. For example, something as simple as plants that can be spread in a room, positively change the student mood and provide the feeling of being surrounded by the nature inside the room. In addition to other Biophilic aspects that can be used in the school's buildings such as covering the roofs with green, creating large windows to allow the natural daylighting to enter the space and provide an access to the outdoor environment.

\subsection{The impact of Biophilic design on the students' health and performance}

The Biophilic design has a great impact on students. According to the studies, the experts have proven that the student's health, performance and mentality are positively influenced by this design strategies (Kellert and Elizabeth, 2015). As there are a strong relation between the nature and the human body systems. These body systems are defined briefly into three senses that are mainly affected the stress, the cognitive functionality and performance and the mood, emotion and preference, and the physiological health and wellbeing as shown in (table 1). Each of which will be explained in more detail in the coming sections.

\subsubsection{Cognitive functionality and performance}

The cognitive function enhances the student's memory restoration, ability of thinking and learning. In addition it has the ability to increase the student's attention, which is required mainly for tasks such as filling paperwork, reading and carrying out calculations or analysis (Kellert, 2008). However, the students are under pressure to have a high concentration which requires a lot of energy consumption and high attention and this may cause weakness in their mentality and unusable cognitive resources (Van den Berg, 2007). Therefore, having a direct connection with nature can provide some mental restoration and this helps in increasing the brain's capacity to focus on tasks.

\subsubsection{Mood, Emotion and Performance}

Research indicates that the experience of nature inside the classrooms, has a great impact on the student's psychological mentality (Alcock, 2013). The psychological part includes their adaptability, emotion and mood. The natural environment can reduce the student's ability for being tension or having anxiety anger, hesitation, exhaustion and the whole mood disturbance ( Barton \& Pretty, 2010; Hartig, 2003). Adapting the Biophilic features inside the classrooms can affect the student's mood by implementing some natural features. The students can feel happier and relaxed through the sense of nature inside the room by the use of some plants such as green walls, pots of flowers or even some portraits with natural pictures on the walls (Hartig, 1991).

\subsubsection{Psychological Health and Wellbeing "Stress reduction"}

The human physical reactions includes the sense of hearing, breathing through the respiratory systems, daily systems and total physical comfort. The reaction of the physiological respond to the nature may cause the relaxation of the muscles, reduces the blood pressure and cortisol is a hormone of stress in the blood flow (park, 2009). Therefore, allowing the natural environment design in the built environment have the ability to reduce the psychological stress (Steg, 2007). 
Table 1. Conclusion for the Biophilic design impact on student's health and performance (Terrapin Bright Green ,2014).

\section{Biophilic Design Elements and}

\begin{tabular}{|c|c|c|}
\hline $\begin{array}{c}\text { Stress } \\
\text { Reduction }\end{array}$ & $\begin{array}{c}\text { Cognitive } \\
\text { Performance }\end{array}$ & $\begin{array}{l}\text { Emotion, mood } \\
\& \text { Preference }\end{array}$ \\
\hline $\begin{array}{r}\text { Reduce } \\
\text { stress }\end{array}$ & $\begin{array}{r}\text { Improve } \\
\text { performance }\end{array}$ & $\begin{array}{r}\text { Improve mental } \\
\text { health }\end{array}$ \\
\hline $\begin{array}{r}\text { Lower } \\
\text { Blood } \\
\text { pressure }\end{array}$ & $\begin{array}{r}\text { Increase } \\
\text { attention of } \\
\text { exploration }\end{array}$ & $\begin{array}{r}\text { Positive } \\
\text { emotional } \\
\text { response }\end{array}$ \\
\hline $\begin{array}{r}\text { Increase } \\
\text { visual } \\
\text { comfort }\end{array}$ & $\begin{array}{r}\text { Increase } \\
\text { concentration }\end{array}$ & $\begin{array}{l}\text { Positive impact } \\
\text { on attitude }\end{array}$ \\
\hline \multirow[t]{3}{*}{$\begin{array}{l}\text { Lower } \\
\text { heart rate }\end{array}$} & \multirow[t]{3}{*}{$\begin{array}{r}\text { Improve } \\
\text { memory } \\
\text { restoration }\end{array}$} & $\begin{array}{r}\text { Improve } \\
\text { perception of } \\
\text { special pleasure }\end{array}$ \\
\hline & & $\begin{array}{r}\text { Improve } \\
\text { comfort and } \\
\text { safety }\end{array}$ \\
\hline & & $\begin{array}{l}\text { Strong pleasure } \\
\text { response }\end{array}$ \\
\hline
\end{tabular}

\section{Frameworks}

Kellert, Elizabeth, and Terrapin Bright Green were the first to introduce the Biophilic design strategies, principles, elements and attributes. In order to define a framework for the designers to apply the Biophilic design to the built environment. Kellert framework was provided to demonstrate the Biophilic design in six elements and 72 attributes. The second framework was developed by environmental consulting and strategic planning firm Terrapin Bright Green (2014). This framework discussed the Biophilic design in principles that combines the nature with the built environment. The third framework was developed in 2015 by Kellert and Elizabeth as they updated the first framework of Kellert. This new framework identifies three categories for the experience of nature and clarifies 24 elements. This research will focus on the third and the last updated framework as it enables designers to more focus on users' physical, mental, or psychological well-being by using the 24 attributes through the space rather than only focusing on natural characteristics.

\subsection{Developed Biophilic Design: The Kellert \& Elizabeth Framework}

In 2015, Kellert and Elizabeth updated framework based on Kellert's first introduced Biophilia framework. This new framework had three categories of experience of nature, classified into 24 attributes of Biophilic design experiences. Three kinds of natural experience called the direct experience of nature, the indirect experience of nature, and the experience of space and place, which are then classified into 24 elements.This research will focus on some of these elements that can be implemented in the classroom's interior design to enhance the student's performance. The highlighted elements inside the table below shows the chosen elements to be discussed in this research.

Table 2. Experiences and attributes of Biophilic design (Adapted by Kellert \& Elizabeth, 2015)

\begin{tabular}{|c|c|c|}
\hline $\begin{array}{l}\text { Direct } \\
\text { Experience } \\
\text { of Nature }\end{array}$ & $\begin{array}{l}\text { Indirect } \\
\text { Experience of } \\
\text { Nature }\end{array}$ & $\begin{array}{l}\text { Experience of } \\
\text { Space and Place }\end{array}$ \\
\hline $\begin{array}{l}\text { - Light } \\
\text { - Air } \\
\text { - Water } \\
\text { - Plants } \\
\text { - Animals } \\
\text { - Weather } \\
\text {-Natural } \\
\text { Landscapes } \\
\text { and } \\
\text { Ecosystems }\end{array}$ & $\begin{array}{l}\text { - Image of } \\
\text { nature } \\
\text { - Natural } \\
\text { materials } \\
\text { - Natural Colors } \\
\text { - Simulating } \\
\text { natural light and } \\
\text { air } \\
\text { - Naturalistic } \\
\text { shapes and } \\
\text { forms } \\
\text { - Natural } \\
\text { Geometries } \\
\text { - Biomimicry }\end{array}$ & $\begin{array}{l}\text { - Prospect and } \\
\text { refuge } \\
\text { - Organized } \\
\text { complexity } \\
\text { - Integration of } \\
\text { parts to wholes } \\
\text { - Transitional } \\
\text { spaces } \\
\text { - Mobility and } \\
\text { wayfinding } \\
\text { - Cultural and } \\
\text { ecological } \\
\text { attachment to } \\
\text { place }\end{array}$ \\
\hline
\end{tabular}




\subsection{Biophilic design elements in the classroom's interior design}

This part will clarify the Biophilic design elements that are chosen to be implemented for this type of buildings "schools" interior design, and how it can be adapted to enhance the student's health and performance. Knowing that there are other elements that can positively affects the student's performance as well. These elements are: Air "natural ventilation, daylight, plants and natural landscapes and ecosystems as a direct experience of nature. Natural colors, natural materials, Image of nature and naturalistic shapes and forms as an indirect experience of nature. Mobility and wayfinding as an experience of space and place.

\subsubsection{Natural Ventilation}

Air is the Natural ventilation, which can have a great impact on human comfort and productivity. There are various ways of ventilation that can be experienced inside the building; variation in temperature, humidity, airflow and barometric pressure. This could be done through the use of windows or more complex engineering strategies in order to have an access with the outside environment (Alencar, 2010; Kellert, 2005).

\subsubsection{Daylighting}

There are different studies that allows the using of daylight strategies in classrooms and determined the student's impact. For example, a study by Yacan (2014) shows that there is a huge impact on the student's behavior and cognitive skills, due to the effect of the daylight on the students in the classrooms. Gelfand and Freed have also asked for the use of daylight in classrooms in order to allow the students to connect with the outdoor environment to enhance the student's and teacher mood (2010). Figure (1) shows an example for daylighting in a classroom, Carshalton, UK

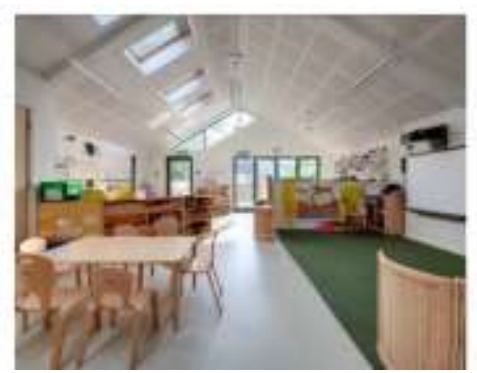

Fig. 1:Daylighting in a classroom, Carshalton, UK (Gower,2019).

Design considerations according to (Gower, 2019).

- Maximize the size of the Windows.

- It could be placed on either sides or on the ceilings.

- Place the seating and tables close to the windows to make the best natural daylighting.

- Move any storages located near the windows, to increase the use of daylight in the spaces.

- Open any shades or remove any signage or artworks that is able to block the daylight from entering.

\subsubsection{Plants}

Other studies have observed the impact of the use of the interior plants in classrooms on the student's performance and perceptions (Doxey, Waliczek, \& Zajicek, 2009). According to these studies they concluded that classrooms with plants is able to increase the rate of performance of the students and enhancing the teacher's feelings by being more involved (Doxey, Waliczek, \& Zajicek, 2009).Actually, these studies was able to advise the use of Biophilic design elements inside the classrooms indifferent ways to positively affect the students. The plants can be adapted in the classrooms through the use of green pots, green walls or even cladding the floors with green patterns as shown in (figure 2). 


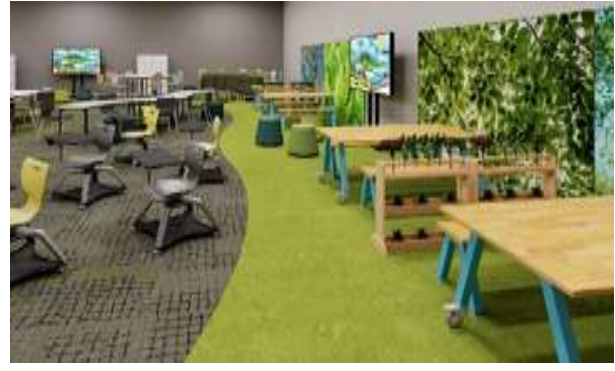

Fig. 2: Classroom design by Stephen Gower in 2019.

\subsubsection{Landscapes and ecosystems}

People usually have a strong inclination toward the natural views over the urban landscapes, as it seems more positive to their emotions and psychological states. In order to increase the linking of natural views in the classrooms, windows should allow the students to be able to watch an urban science including trees and other vegetation. According to the expert's analysis, they clarified, that the movement of the natural views seems to be more positively than the mechanical movement and shifting our attention to something natural is beneficial for attention restoration (Stephen Gower, 2019).

\subsubsection{Natural Colors}

According to the experts color is the third most influential element on students' behaviors in special classrooms behind daylighting and window views. For current the most used colors in schools are the white and brown; white for the floors and ceilings, brown as most of the classrooms are wood. Colors allows the students to feel comfort and relaxed and behave as if they are staying at home. There are two types of colors; warm colors and soft colors as shown in figure
(3)

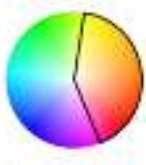

Wercichente
(Gower,

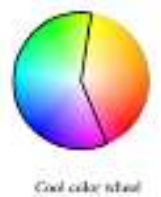

2019).

Fig. 3: warm and cool color wheel (Gower, 2019).

Some of the experts clarified that it is better to use the soft, warm and calm colors than the cool, dark and high saturated colors in schools. As the harmony of warm colors is able to provide the students with comfortable atmosphere. Moreover, the interaction of the colors with the daylighting, allows the atmosphere to positively affect the teachers perceptions, not only the student's ability of learning (Gower, 2019).

Design considerations:

- Use warm and calming natural harmonies tones of color pallets (Miller, 1997).

- Use colors that affects the emotions (Birren, 2006), as shown in figure (4).

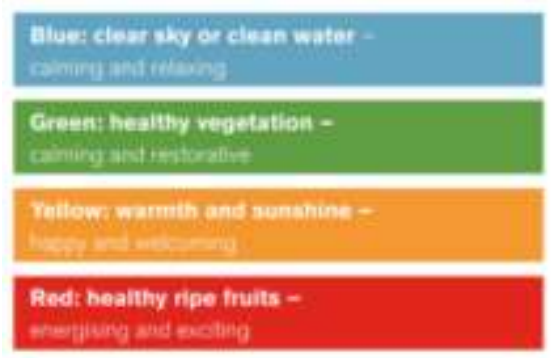

Fig. 4: Colors that affects the emotions (Birren, 2006).

\subsubsection{Natural Materials}

According to the reference of the Biophilic natural materials and patterns, textures or colors, when they are inspired from the nature they can affect our feeling with positive physiological effect. For example, the use of wood in the interiors can be able to decrease the blood pressure and maximize the feeling of comfort (Tsunetsugu, miyazaki \& Sato 2007). Wood can be used in classrooms; in desks, chairs, flooring and shelves (Gower, 2019).

\subsubsection{Image of Nature}

Image of nature is an indirect way to feel the nature features; plants, water, animals, through the use of portraits, paintings, photographs, sculptures and other means of art (Alencar, 2010). 


\subsubsection{Natural shapes and forms}

Naturalistic shapes and forms could be used on the decoration of the Building's interior or exterior facades. In case of maintaining the Biophilic design it should be inspired from nature; for examples shapes of animals or plants as patterns on an exterior façade or a column. The creation of these shapes could be able to transform a space from a static state to a dynamic living system with a spiritual feeling of movement (Alencar, 2010; Kellert, 2005).

\subsubsection{Mobility and wayfinding "Space}

\section{Layout"}

Mobility and wayfinding is the way of movement through the building is very important to be easy and flexible, so that people can feel comfort and satisfied (Kellert and Calabrese, 2010). The flexibility of movement can be adapted in the classrooms according to the layout furniture arrangement. In practice, one of the studies explained that a rectangular layout increases space utilization, while a circular layout is useful for better communication between students and the teacher. They also demonstrated that when the furniture was in a circular layout arrangement, the students showed a sense of collaboration and high

\section{Research Method}

This research adopts a mixed method approach where both qualitative and quantities approaches will be used into three parts. These parts are the factors that affects the student's health and performance and they are collected from the literature review according to the studies and analysis to implement a checklist matrix. In order to help the researcher or a designer to identify the suitable Biophilic design strategies to be adapted in the classroom's interior design to enhance the student's health and performance. The first part analyze how stress affects the student's performance using Biophilic design

strategies. The second part analyze the student's cognitive performance through the impact of the Biophilic design elements to enhance the memory restoration, attention, concentration and performance. The last part clarifies how the student's emotion, mood and preferences could be affected from the Biophilic elements. The last part identifies the Biophilic nine elements. The three parts are grouped with the Biophilic design elements deduced from the literature review in a matrix. This matrix will be filled by the researcher to deduct a guidelines to use the Biophilic design elements in an efficient way to enhance the student's health and performance. 


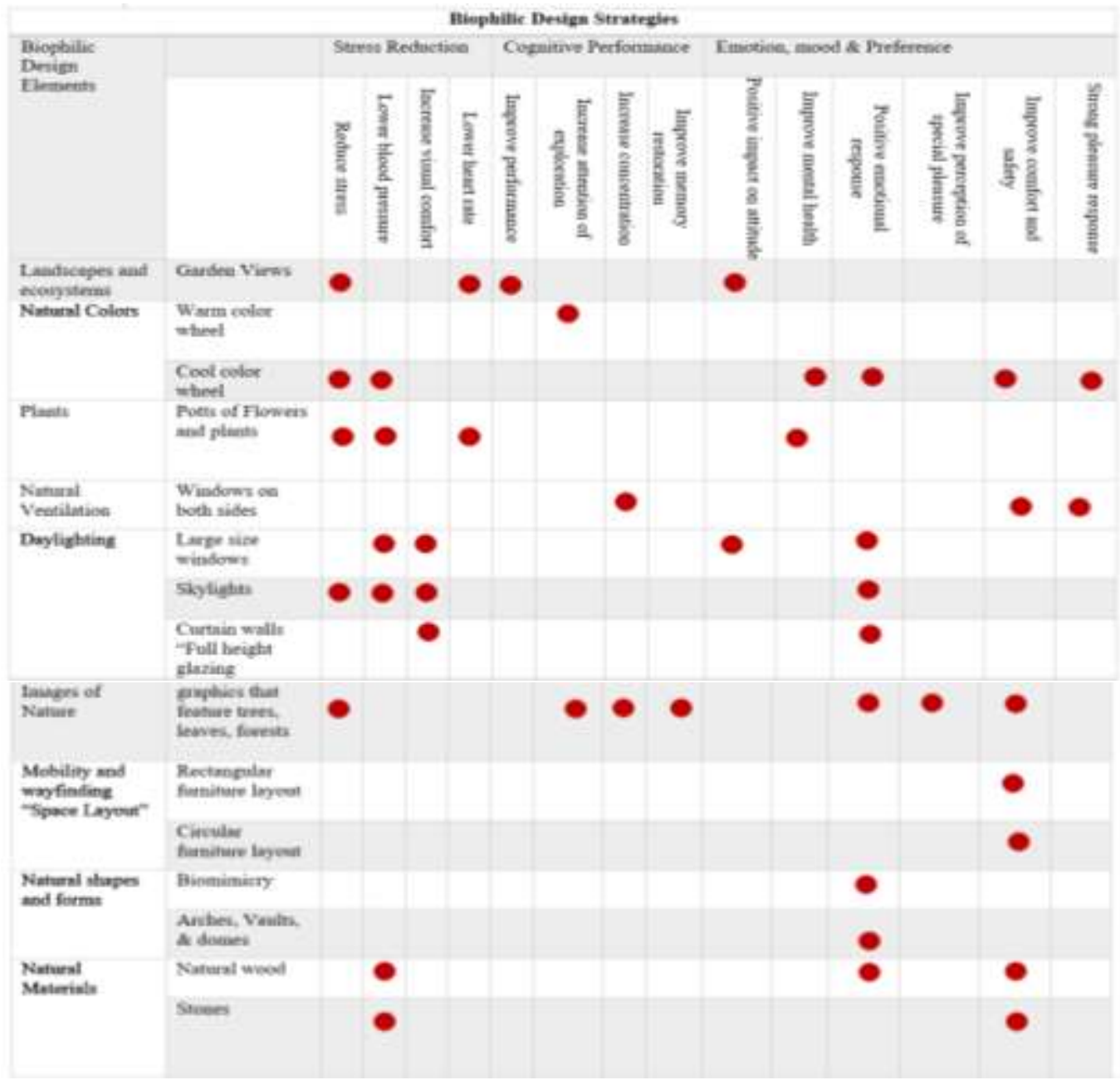

Fig. 5: Final checklist (matrix) linked the Biophilic design elements with the student's health and performance according to the literature review.

\section{Guidelines for integrating Biophilic design elements according to the matrix results.}

There are different studies that has discussed the Biophilic design frameworks and how it affects the human health and wellbeing .On the other hand, neither one of them focused on the specific Biophilic design elements to be adapted in the classroom's interior design to enhance the student's health and performance. This research aim is to provide a matrix according to the literature review data that is able to help the designer to implement the Biophilic design strategies in the classroom's interior design. The results of this matrix was to identify the efficient Biophilic design strategies and how it can be implemented in the classrooms according to the student's stress reduction, cognitive performance and emotion mood and preferences. The results according to the matrix are classified into eight points according to the Biophilic elements; Landscapes and ecosystems, Natural colors, plants, Natural ventilation, daylighting, images of nature, natural materials, natural shapes and forms and the space layout. In order to implement the 
suitable Biophilic design strategies according to the student's comfort and satisfaction.

- Landscapes and ecosystems: according to the literature review data it has a great impact on the student's satisfaction. The classroom's seats should be oriented towards the windows to allow the students to feel the outside environment through views of the gardens. As the results of the matrix clarified that the garden views as able to lower blood pressure, lower heart rate, improve performance, increases the concentration and positively affects the student's mood (Brown, Barton \& Gladwell, 2013; van den Berg, Hartig, \& Staats, 2007).

- Natural Colors: According to the matrix it is better to use the soft, warm and calm colors than the cool, dark and high saturated colors in schools. As the harmony of warm colors is able to provide the students with comfortable atmosphere due to the studies of Gower in 2019.

- Plants: There are two ways to use the plants inside the classrooms either natural plants in pots or artificial plants. The use of natural plants and flowers pots inside the classrooms is better according to the matrix, as it is able to enhance the air and atmosphere inside the classroom and increase the student's productivity, memory restoration and reduce the stress. The matrix result was done due to the studies of Heerwagen in 2006.

- Natural ventilation: according to the literature review data it is better to use large size of windows on both sides of the classroom to enhance the natural ventilation (Gower, 2019). In

- a space from a static state to a dynamic living system with a addition to the matrix results, which shows the impact of the natural ventilation on the student's comfort and enhanced the concentration (Heerwagen, 2006; Tham \& Willem, 2005; Wigö, 2005).

- Daylighting: The research literature review clarified the different ways to implement the suitable daylighting. This could be done according to having skylight openings in the ceilings, large windows on both sides of the classroom, full height glazing. According to the matrix using large the size of windows on both sides will be better than the other two solutions to eliminate the sense of glare and increases the visual comfort. As the daylighting has a great impact on the student's behavior and cognitive through the increase of concentration, positive emotional response and improve the perception of spatial pleasure (elyezadi, 2012; Kim \& Kim, 2007).

- Images of Nature: The results of the matrix shows how to allow the sense of nature indirectly by the use of graphics that feature trees, leaves, forests inside the classrooms. In order to allow the students to feel comforted and surrounded by the outdoor environment. Therefore, Images of nature is able to reduce the student's stress, improve their memory restoration and increased their attention according to the matrix results due to the studies of Berman, Jonides and Kaplan in 2008.

- Natural materials: wood is the main feature that is mostly used in the classroom's floors and furniture. Wood can be used in classrooms; in

spiritual feeling of movement. The matrix results shows that the use of 
natural shapes and forms has a positive emotional response due to the studies of vessel in 2012 and Joye in 2007.

- $\quad$ Space layout: The matrix shows that it is better to arrange the furniture in a circular layout as it affects the student's sense of collaboration and high concentration (Grahn \& Stigsdotter, 2010; Wang \& Taylor, 2006).

\section{Applicable Study}

The chosen case study is an international school called "Malvern Collage Egypt" one of the high quality standard schools established in 2016 and located in the New Cairo, Egypt. The project is a large $U$ shaped building surrounded by a green area and large swimming pool. The school education levels starts from kindergarten till the high school level. The criteria for choosing this school as it is one of the few schools in Egypt that adapted some of the Biophilic elements; it focused on enhancing the student's comfort and satisfaction through the use of natural design elements inside the classrooms. In addition to the overall conditions of the school design. In order, to be an example for other schools to adapt a new design ideas in the future to enhance the student's comfort The data collection was classified into two steps .The first step of collecting the data was a field survey to the schools' campus to take the possible photos for the primary classrooms in the real conditions and taking notes. The second step was using these photos and notes to fill the deduced matrix in order to identify how many element of the Biophilic features are present. Finally, according to the filling of the matrix, (table 3) will identify the Biophilic elements that are present in the classroom and what should be added to enhance the Biophilic design natural elements inside the school.

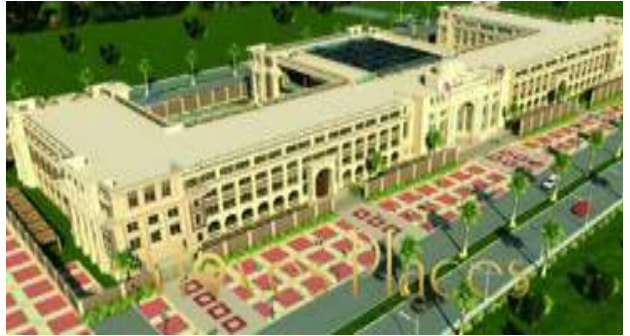

Fig. 6: The main gate for Malvern College School.

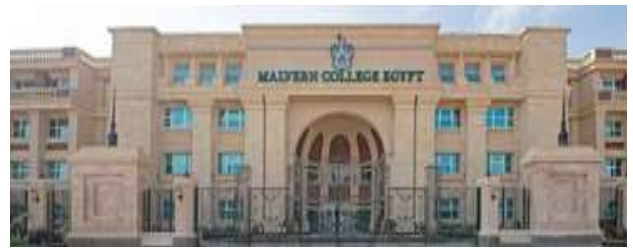




\begin{tabular}{|c|c|c|}
\hline $\begin{array}{l}\text { Biophilic } \\
\text { Design } \\
\text { Elements }\end{array}$ & & 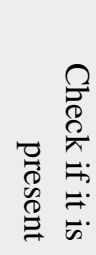 \\
\hline $\begin{array}{r}\text { Landscap } \\
\text { es and } \\
\text { ecosyste } \\
\text { ms }\end{array}$ & Garden Views & \\
\hline \multirow[t]{2}{*}{$\begin{array}{l}\text { Natural } \\
\text { Colors }\end{array}$} & Warm color wheel & \\
\hline & Cool color wheel & \\
\hline Plants & $\begin{array}{r}\text { Potts of Flowers } \\
\text { and plants }\end{array}$ & \\
\hline $\begin{array}{r}\text { Natural } \\
\text { Ventilati } \\
\text { on }\end{array}$ & $\begin{array}{r}\text { Windows on both } \\
\text { sides }\end{array}$ & \\
\hline \multirow[t]{3}{*}{$\begin{array}{r}\text { Daylighti } \\
\text { ng }\end{array}$} & Large size windows & \\
\hline & Skylights & \\
\hline & $\begin{array}{r}\text { Curtain walls "Full } \\
\text { height glazing }\end{array}$ & \\
\hline $\begin{array}{r}\text { Images } \\
\text { of Nature }\end{array}$ & $\begin{array}{l}\text { graphics that } \\
\text { feature trees, } \\
\text { leaves, forests }\end{array}$ & \\
\hline $\begin{array}{r}\text { Mobility } \\
\text { and } \\
\text { wayfindi }\end{array}$ & $\begin{array}{r}\text { Rectangular } \\
\text { furniture layout }\end{array}$ & \\
\hline $\begin{array}{r}\text { ng } \\
\text { "Space } \\
\text { Layout" }\end{array}$ & $\begin{array}{r}\text { Circular furniture } \\
\text { layout }\end{array}$ & \\
\hline \multirow{2}{*}{$\begin{array}{r}\text { Natural } \\
\text { shapes } \\
\text { and } \\
\text { forms }\end{array}$} & Biomimicry & \\
\hline & $\begin{array}{r}\text { Arches, Vaults, \& } \\
\text { domes }\end{array}$ & \\
\hline \multirow[t]{2}{*}{$\begin{array}{r}\text { Natural } \\
\text { Materials }\end{array}$} & Natural wood & \\
\hline & Stones & \\
\hline
\end{tabular}

6.1. Biophilic elements guideline matrix

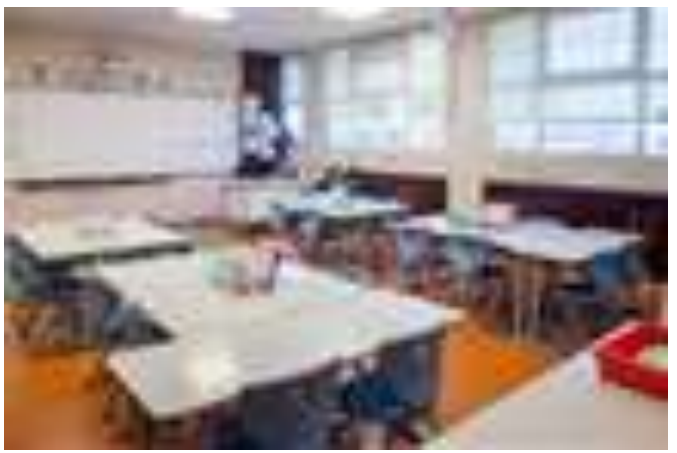

Fig. 8: Malvern Collage Primary classroom.

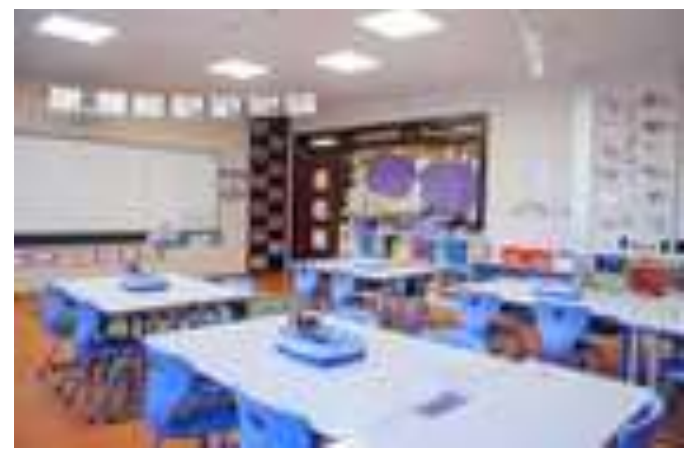

Fig. 9: Malvern Collage primary classroom from another prospective 


\subsection{Discussion and Recommendations} Table 5: Analysed the pressent Biophilic elements and what are the recommended elements to enhance the Biophilic design inside the classroom , according to the case study filling matrix.

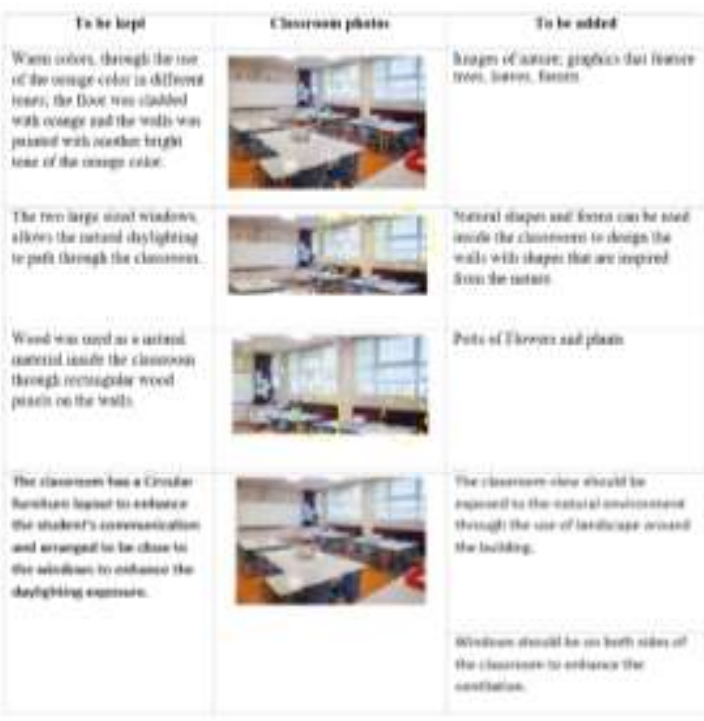

\section{Conclusion}

This research aim to implement the Biophilic design strategies and identify the suitable and efficient way to be implemented to enhance the student's health and performance inside the classrooms, through the use of the deduced checklist (matrix) in Egypt's schools. The matrix was effective to this research as it clarifies the efficient nine Biophilic elements and how it can be adapted to reach the highest satisfaction for the student's health and performance. In addition to the use of Malvern College School as a case study to show an example of one of the Egypt's schools that started to use the natural elements inside the classrooms to enhance the student's comfort. This case study was used to support the aim of the research to start implementing the Biophilic design elements inside the schools. The Biophilic design elements don't based on the school quality standard, they are sustainable elements that are affordable to be used through different types of schools (international or even public). It is a new design strategy that started to be used in all over the world and expected to be more desired for the future.

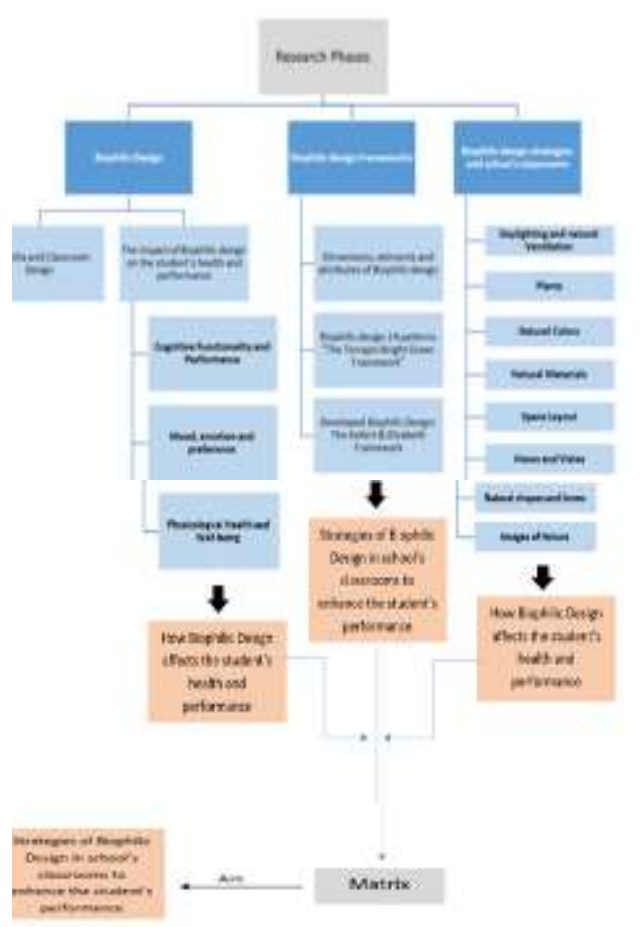

Fig. 10: Research Phases 


\section{References}

1. Louv, R.(2008). Children and the success of biophilic design. In J. H. Kellert, J.H. Heerwagen, \& M.L. Mador (Eds.), Biophilic design: The theory ,science, and practice of bringing buildings to life (pp.205-223). Hoboken, NJ: John Wiley \& Sons. 2. Moore, R.C., \& Marcus, C.C. (2008). Healthy planet, healthy children: designing nature into the daily spaces of childhood. In S.R. Kellert, J.H. Heerwagen, \& M.L. Mador (Eds.), Biophilic design: The theory ,science, and practice of bringing buildings to life (pp.153- 203). Hoboken, NJ: John Wiley \&

Sons.

3. Kellert, S. (2005). Building for life: Designing and understanding the human nature connection. Washington, DC: Island Press. Kellert, S (2008). Dimensions, elements, and attributes of biophilic design. In S.R. Kellert, J.H. Heerwagen, \& M.L. Mador (Eds.), Biophilic design: The theory, science, and practice of bringing buildings to life (pp.3-19). Hoboken, NJ: John Wiley \& Sons. 4. Heerwagen, J.H. \& B. Hase (2001). Building Biophilia: Connecting People to nature in Building Design. uS Green Building Council. Posted march 8, 2001. http:// www.usgbc.org/Docs/Archive/external/Docs 8543. pdf. Web. 9 July 2013.

5. Heerwagen, J.H. (2006). Investing In People: The Social Benefits of Sustainable Design. Rethinking Sustainable Construction. Sarasota, FL. September 19-22, 2006.

6. Heerwagen, J.H. \& G.H. Orians (1993). Humans, Habitats and Aesthetics. In: S.R. Kellert \& R.S. Wilson (eds.). The Biophilia Hypothesis (138-172). Washington: Island Press. pp484. Heerwagen, J.H. (2014). J.H.

7. Heerwagen \& Associates; university of Washington, Department of Architecture.

Personal communication with the authors.

8. Kellert, S.R. \& e.O. Wilson (1993). The Biophilia Hypothesis. Washington: Island Press. pp484. Kellert, S.F. \& B. Finnegan (2011). Biophilic Design: the Architecture of Life (Film). Bullfrog Films.
9.Kellert, S.F., J.H. Heerwagen, \& m.L. mador eds. (2008). Biophilic Design: The Theory, Science \& Practice of Bringing Buildings to Life. Hoboken, nJ: John Wiley \& Sons.

10. Clements-Croome, D. (2018, April 12). Designing for flourishing environments. Retrieved from CIBSE: https://www.cibse.org/getmedia/871fc22888fc-4675-b2244cb12a5642d6/TS2018-122Clements-Croomeslides.aspx

11. Gillis, K., \& Gatersleben, B. (2015, August). A Review of Psychological Literature on the Health and Wellbeing Benefits of Biophilic Design. Buildings, 5, 948-963.

12. Kaplan, S. (1995, September). The Restorative Benefits of Nature: Toward an Intergrative Framework. Journal of Environmental Psychology, 15(3), 169-182. 13. Bowman, R. (2018, January). ARCC Green Infrastructure Design Challenge 2018. Retrieved from RCZM: http://www.rczm.co.uk/PDF/ARCC\%20Gree $\mathrm{n} \% 20$

Infrastructure\%20Challenge\%202018.pdf 14. Browning, W.D., Ryan, C., Kallianpurkar, N., Laburto, L., Watson, S., Knop, T. 2012. The Economics of Biophilia, Why Designing with Nature in Mind Makes Financial Sense. New York: Terrapin Bright Green.

15. Browning, W.D., Ryan, C., Clancy, J. 2014. 14 Patterns of Biophilic Design, Improving Health \& Well-Being in the Built Environment. New York: Terrapin Bright Green. 16.Kaplan, S., R. Kaplan, and R. Ryan. 1998. With People in Mind: Design and M01uzgement of Everyday Life. Washington, DC: Island Press. 


\section{دمج وتكامل إستراتيجيات التصميم الداخلي مع التصميم الحيوي (البيوفيليا ) بهاف تعزيز أداء الطلاب المدارس الابتدائية في مصر التهري}

تعتبر المدارس من أهم المباني التي تؤثر على أسلوب حياة الجيل و طريقة تفكيره،و تعد مصر واحدة من الدول التي نواجه التها

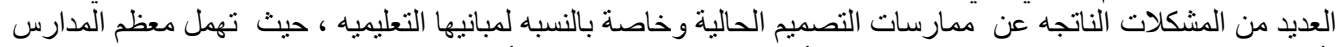

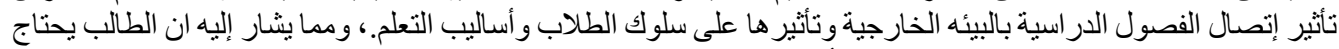

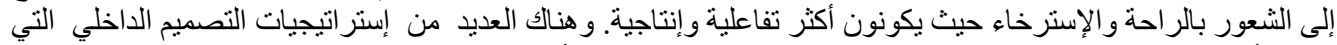

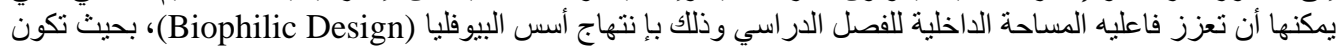

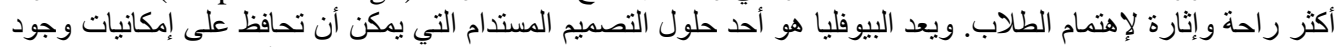

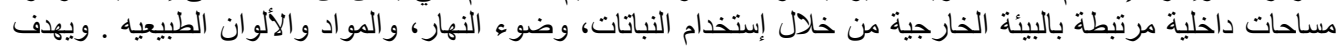

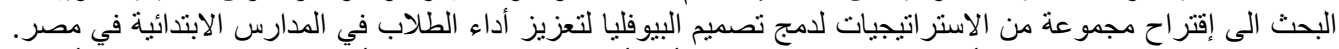

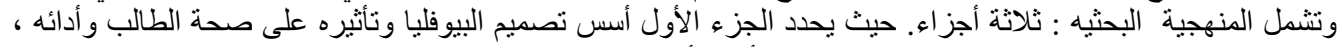

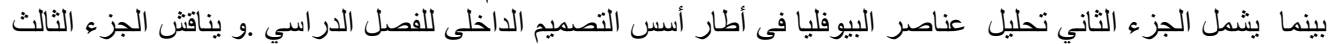

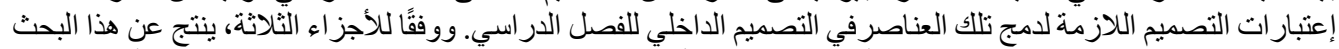

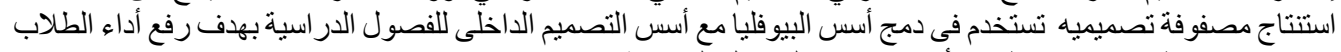
وبحيث يمكن تطبيقها بهدف تطويرو أعادة تصميم الفصول الدئر اسية.

الكلمات المفتاحية: التصميم الحيوي ، المساحات الخضر اء الداخلية ، التعليم في مصر ، استر اتيجيات التصميم ، أداء 